\title{
Biochemical Markers of Bone Turnover in Rheumatoid Arthritis Patients Treated with Glucocorticoids
}

\author{
LUANA ANDREEA MACOVEI ${ }^{2 *}$, ALEXANDRA BURLUI ${ }^{1}$, ELENA REZUS ${ }^{2}$ \\ ${ }^{1}$ Grigore T. Popa University of Medicine and Pharmacy lasi, Department of Rheumatology, Rehabilitation, Physical Medicine and \\ Balneology, 16 Universitatii Str., 700115, Iasi, Romania \\ ${ }^{2}$ Clinical Rehabilitation Hospital of lasi, $1^{\text {st }}$ Rheumatology Clinic, 14 Pantelimon Halipa, 700656, Iasi, Romania
}

\begin{abstract}
Osteocalcin and deoxypyridinoline levels were measured in 55 RA patients during and after glucocorticoid therapy with prednisone, methylprednisolone and cortisone. A decrease of $27 \%$ of the bone resorption marker deoxypyridinoline (from 10.13 to 7.4) and an increase of 23\% of the bone formation marker osteocalcin (from 16.3 to 20.1) were also clinically confirmed by the presence of osteoporosis in $74 \%$ of patients receiving corticosteroid treatment as compared with only $31 \%$ in the control group.
\end{abstract}

Keywords: glucocorticoids, osteocalcin, deoxypyridinoline

Glucocorticoids, steroid hormones produced by the adrenal cortex, play a role in bone development by regulating osteoblast differentiation. Glucocorticoids preserve bone integrity also by suppressing cells that produce proinflammatory cytokines, such as TNF- $\alpha$, IL - - , IL -6 and IL -17 . When synthetically produced and supplemented, glucocorticoids have an anti-inflammatory effect. However, glucocorticoids act both on immune cells and stromal cells, such as synovial fibroblasts, chondrocytes and osteoblasts [1-5]. Therefore, high levels of glucocorticoids have negative effects on osteoblasts and osteocytes, leading to decreased bone mineral density, first in the trabecular bone and, if it is left untreated, also in the cortical bone. Glucocorticoid use has a slightly stronger impact on the trabecular bone than on the cortical bone and the spine is more affected than the hip.

Glucocorticoids successfully control symptoms and reduce the erosion progression in rheumatoid arthritis (RA), a disease that also induces periarticular bone erosions, osteonecrosis and osteoporosis, leading to an increased risk of hip and vertebral fractures, with bone changes similar to those seen in aged individuals [6-9]. The fracture risk is further increased by the fact that muscle weakness caused by glucocorticoid-induced myopathy make RA patients treated with steroids prone to falling [10].

The adverse effects of glucocorticoid supplementation on bones, expressed as osteoporosis and osteonecrosis, are dose-related. In osteocytes, high doses of glucocorticoids induce apoptosis and low doses induce autophagy. EULAR 2016 guidelines recommend the use of the lowest dose possible for a period of less than 6 months in RA patients [11]. Low-dose prednisolone can be defined as levels between 2.5 and $10 \mathrm{mg}$ per day. Doses of prednisolone higher than $7.5 \mathrm{mg}$ per day are a risk factor for osteoporosis. Other systemic corticosteroids include prednisone, methylprednisolone and dexamethasone. It is estimated that about one in two RA patients receives glucocorticoid therapy and that after 6 months of glucocorticoid therapy, $25 \%$ of them show decreased bone mineral density in the trabecular bone $[12,13]$.

On the other hand, biologic therapy, the anti TNF-á therapy (e.g. etanercept, infliximab, adalimumab, certolizumab pegol, golimumab), shows no bone adverse effects, but other side effects, such as malignancy and cardiovascular disease raise concerns among practitioners. For that reason, in RA patients, the bone destruction caused

\footnotetext{
*email: Iuanam77@yahoo.com; Phone: +40)745313814
}

by glucocorticoids should be outweighed against the positive anti-inflammatory effects of glucocorticoids, which prevent bone erosion. Furthermore, osteoporosis diagnosed in RA patients treated with glucocorticoids may also involve other etiological factors, such as age, sex, disease activity, duration of disease, lifestyle and the concomitant use of other drugs. Osteoporosis can be prevented by supplementation with calcium $(1,000-1,500$ $\mathrm{mg} / \mathrm{d})$ and vitamin $\mathrm{D}(800 \mathrm{lU} / \mathrm{d})$, due to the fact that glucocorticoids decrease gut calcium absorption while increasing urinary calcium excretion [14]. Bisphosphonates are also used for preventing the glucocorticoid-induced loss of bone mineral density.

Serum and urine biochemical markers may help assess bone formation and resorption. Bone is made of calcium hydroxyapatite (60\%) and proteins - type I collagen (40\%). The destruction and regeneration of both components can be estimated by the levels of chemical breakdown compounds in blood (serum and plasma) and urine (table $1)$.

Proteins and enzymes such as alkaline phosphatases, osteocalcin and procollagen breakdown products (procollagen type I carboxy-terminal propeptide - PICP and $\mathrm{N}$-terminal propeptide of type I procollagen - PINP) express bone formation.

Alkaline phosphatase is a glycosylphosphatidylinositol protein. The expression of this enzyme is influenced by $1,25(\mathrm{OH}) 2 \mathrm{D} 3$ (vitamin D). Its role is to remove phosphate groups from the molecules of proteins or nucleotides. Alkaline phosphatase is an orthophosphoric mono-ester phospho-2-hydrolase. Bone Gla protein or gammacarboxyglutamic acid containing protein, known as osteocalcin, has a molecular weight of $58 \mathrm{kDa}$ and 49 amino acids. This noncollagenous protein contains three residues of $\gamma$-carboxyglutamic acid per molecule. $\mathrm{ACOOH}$ group is added to the glutamic acid residues with the help of vitamin K, forming $\gamma$-carboxyglutamic acid moieties [15]. About $36 \%$ of serum immunoreactive osteocalcin is the intact protein, $30 \%$ is made of residues 1-43 of a N-midmolecule fragment and the rest consists of even smaller residues [16]. The procollagen type I carboxy-terminal propeptide (PICP) is a trimeric soluble globular polypeptide protein which is stabilized by interchain disulphide bridges. It has a molecular weight of $100 \mathrm{kDa}$. The procollagen type I amino-terminal propeptide (PINP) is a protein with a molecular weight of $35 \mathrm{kDa}$ and globular structures which also contain helix. 
Table 1

SERUM AND URINE MARKERS OF BONE TURNOVER

\begin{tabular}{|c|}
\hline Serum bone formation markers \\
\hline Alkaline phosphatase \\
\hline Osteocalcin \\
\hline Procollagen I N terminal extension pro-peptide (PINP) \\
\hline Procollagen I C terminal extension peptide (PICP) \\
\hline Serum bone resorption markers \\
\hline C-terminal type I collagen telopeptide (CTX) \\
\hline N-terminal cross-linking telopeptide of type I collagen (NTX) \\
\hline C terminal telopeptide (ICTP) \\
\hline Tartrate resistant acid phosphatase $5 \mathrm{~b}$ (TRACP5b) \\
\hline Urine bone resorption markers \\
\hline C-terminal type I collagen telopeptide (CTX) \\
\hline N-terminal type I collagen telopeptide (NTX) \\
\hline Helical peptide $620-633$ from the alchain of type I collagen \\
\hline Pyridinoline \\
\hline Hydroxylyzine and its glycosides (e.g. galactosyl-hydroxylyzine) \\
\hline Deoxypyridinoline \\
\hline Hydroxyproline \\
\hline
\end{tabular}

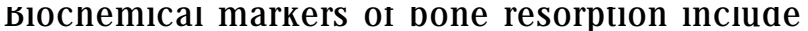
breakdown product of collagen, cross-linking compounds of collagen or enzymatic telopeptide cross-linking molecules (pyridinoline, deoxypyridinoline, carboxyterminal telopeptide of type I collagen - CTX-I, aminoterminal telopeptide of type I collagen - NTX-I), proteins (bone sialoprotein, sclerostin, osteopontin, periostin, Dickkopf-related protein 1 - Dkk-1), compounds of amino acids (helical peptide 620-633 from the al chain of type I collagen), matrix-metalloprotease (MMP)-generated telopeptide peptides (CTX-MMP or ICTP) and osteoclastic enzymes (hydroxyproline, hydroxylysine, hydroxylysine glycoside, tartrate-resistant acid phosphatase subform b of the isoenzyme 5 and cathepsin K). The telopeptides are nonhelical peptide fragments of type I collagen. Sclerostin is a cysteine-knot protein having 188 amino acids with 2 $\mathrm{N}$-glycosylation sites. The glycoside is formed by oxidation collagen lysine and glycosylation. Bone sialoprotein is a phosphorylated glycoprotein with a molecular weight of $33 \mathrm{kDa}$ and of up to $80 \mathrm{kDa}$, when glycosylated. Osteopontin belongs to the small integrin-binding ligand $\mathrm{N}$-linked glycoprotein (SIBLING) family and periostin is an adhesion molecule expressed in the periosteum. Cathepsin $\mathrm{K}$ is an enzyme which belongs to the CA1 family of Iysosomal cysteine proteases. It cleaves both helical and telopeptide regions of collagen type I [17]. TRACP 5b is a protein cleaved in tw o subunits. In vitro, cathepsin $\mathrm{K}$ cleaves TRACP and produces reactive oxygen species involved in matrix degradation by transcytosis. CTX-1, which is released by cathepsin $\mathrm{K}$, contains a crosslink molecule and its aspartate-glycine sequence undergoes b-isomerization and racemization. Urinary levels of $C$-terminal telopeptide of type II collagen (CTX-II) were linked to joint erosion. The helical peptide $620-633$ is found on the al chain of type I collagen. Pyridinoline and deoxy-pyridinoline are nonreducible cross-links formed by the condensation of lysine and hydroxylysine residues in the telopeptide regions and in the helical regions of adjacent collagen molecules [18].

Rheumatoid arthritis has several diagnostic and prognostic markers, in the form of cytokines, antibodies, alarmins, soluble receptors and other functional molecules: rheumatoid factor (RF), anti-citrullinated protein antibodies (ACPAs) and also the erythrocyte sedimentation rate (ESR) and C-reactive protein (CRP), which are inflammation markers non-specific to rheumatoid arthritis [19]. Due to the fact that RF and ACPAs have shown limited sensitivity and that rheumatoid arthritis is a complex disease, novel biomarkers are currently investigated, as a combination of markers is required to predict the course of the disease [16]. For instance, ICTP levels help express the bone resorption and destruction seen in rheumatoid arthritis. Increased cathepsin $\mathrm{K}$ levels have been reported in patients with active rheumatoid arthritis. Therefore, cathepsin $\mathrm{K}$ inhibitors have been studied as potential agents for the treatment of rheumatoid arthritis. Increased circulating Dkk-1 levels have been also reported in rheumatoid arthritis patients with highly depressed bone formation and osteolysis [20].

Other markers, which may be used in rheumatoid arthritis include MMP-3, MMP-1, RANKL, type I and II collagen degradation, tissue inhibitor of metalloproteinases- 1 and chondroitin sulfate epitope 846 (CS846) from agreccan molecules [21].

\section{Experimental part}

\section{Materials and methods}

A total number of 55 patients who were diagnosed with RA at the first Rheumatology Clinic of Clinical Rehabilitation Hospital of lasi were investigated between January 2017 and June 2018. All patients agreed to participate in the study.

In order to study the changes in bone turnover in patients receiving glucocorticoid therapy, the RA patients were divided into two groups. The study group consists of 23 patients $(41.81 \%)$ who were treated with glucocorticoids (prednisone, methylprednisolone and cortisone). $87 \%$ of the study group patients were aged over 40 years, with $89 \%$ female patients and $11 \%$ male patients. The control group includes 32 patients (58.19\%) with no glucocorticoid therapy. $81 \%$ of the control group were aged over 40 , with $79 \%$ female patients and $21 \%$ male patients.

The levels of osteocalcin in blood were measured by using the radioimmunoassay ELISA OST NAT with a normal range of osteocalcin in women of $5.3-23.6 \mathrm{ng} / \mathrm{mL}$. The kit sensitivity was $0.3 \mathrm{ng} / \mathrm{mL}$. Serum osteocalcin occurs in severals forms: carboxylated osteocalcin, undercarboxylated osteocalcin, total osteocalcin levels. Commercial kits as the one used in our study are sensitive to fully decarboxylated osteocalcin. Studies in mice suggest that undercarboxylated osteocalcin has physiological significance [22].

Urinary free deoxypyridinoline levels were measured by automated chemiluminescence immunoassay (Automatic Chemoluminescent System, Chyron). The results were expressed as a ratio of deoxypyridinolines measured per mmol of urinary creatinine, in order to avoid biases caused by variations in urine concentration. The measurement was performed on the second morning urine, to avoid circadian variations of deoxypyridinoline of up to $30 \%$ during $24 \mathrm{~h}$. Normal levels of deoxypyridinolin were considered $5-40 \mathrm{nmol} / \mathrm{mmol}$ of urinary creatinine in 
Table 2

BONE MARKER LEVELS IN HEALTHY INDIVIDUALS

\begin{tabular}{|l|l|}
\hline Bone markers & Normal range \\
\hline Osteocalcin & $9-42 \mathrm{ng} / \mathrm{mL}$ \\
\hline Alkaline phosphatase & $45-140 \mathrm{U} / \mathrm{L}$ \\
\hline $\begin{array}{l}\text { Procollagen type I amino-terminal } \\
\text { propeptide/PINP }\end{array}$ & $16-96 \mathrm{mcg} / \mathrm{L}$ \\
\hline Deoxypyridinoline & $\begin{array}{l}1.3-6.9 \\
\mathrm{dpd} / \mathrm{nm}\end{array}$ \\
\hline
\end{tabular}

menopausal women and $10-60 \mathrm{nmol} / \mathrm{mmol}$ of urinary creatinine in postmenopausal women (table 2 ).

\section{Results and discussions}

In our study group, the biochemical markers of bone turnover were assessed again after an average period of 8 months of glucocorticoid treatment cessation (table 3). A decrease of $27 \%$ of the bone resorption marker deoxypyridinoline (from 10.13 to 7.4) and an increase of $23 \%$ of the bone formation marker osteocalcin (from 16.3 to 20.1) were also clinically confirmed by the presence of osteoporosis in $74 \%$ of patients receiving corticosteroid treatment as compared with only $31 \%$ in the control group.

All 55 investigated patients had a long duration of rheumatoid arthritis, as follows: an average of 9 years in the study group who has received glucocorticoids and 7 years in the control group with no glucocorticoid treatment. There were no cases of early stage rheumatoid arthritis, when the anti-inflammatory effects of glucocorticoids may counterbalance their negative effects on bone formation and resorption [23].

Osteocalcin concentrations tend to be significantly lower in RA patients. Even if alkaline phosphatase is also decreased, its presence may also indicate high disease activity in RA patients, due to the fact that the synovial tissue may be a source of alkaline phosphatase and rheumatoid arthritis is characterized by persistent synovitis.

The increased bone resorption found in rheumatoid arthritis patients is indicated by higher concentrations of CTX, TRACP 5b, and pyridinoline. High levels of procollagen type I amino-terminal propeptide (PINP) are found in the presymptomatic phase of rheumatoid arthritis [24].

Rheumatoid arthritis is characterized by intense lipid peroxidation and protein oxidation, due to the increased levels of oxidants, cytokines, eicosanoids, and catabolic enzymes. Acute destructive RA increases bone resorption and inhibits bone formation. The assessment of bone turnover is useful for identifying patients with fracture risk caused by the increased bone resorption and for evaluating the response to antiresorptive treatment. High levels of bone markers are correlated with marked bone loss and increased risk of fracture. In these cases, therapy should be immediately initiated.

Almost all treatments of rheumatoid arthritis lead to increased levels of procollagen type I amino-terminal propeptide (PINP). Nevertheless, PINP levels may remain stable following infliximab use or even decrease after denosumab therapy [25].

Biological therapy has a beneficial effect on bone formation, which is show $n$ by the increased levels of serum osteocalcin, decreased NTX-I, CTX-I, ICTP levels following infliximab therapy and the increase in serum levels of amino-terminal type I procollagen propeptide due to tocilizumab use. Methotrexate leads to a decrease of urinary NTX-I after 6 months of use.

There are no statistically significant differences between CTX-I or TRAP5b levels in patients treated with and without bisphosphonates [26].

Prednisone use may result in a decrease in CTX-I and ICTP levels, even if bone resorption increases at the beginning for a short period of time.

Glucocorticoid therapy negatively impacts bone formation. Glucocorticoids induce bone loss by inhibiting the activity and genesis of osteoblasts. Glucocorticoids have a catabolic effect on protein metabolism, because they promote hydrolysis and prevent synthesis of proteins [27]. Glucocorticoids cross the cell membrane into the cytoplasm. Active cortisol, converted by the 11b-HSD enzymes, binds to the glucocorticoid receptor, which translocates into the nucleus. Due to the fact that glucocorticoids affect mostly the trabecular bone and to a lesser extent the cortical bone, spine and rib fractures are more common than hip fractures in patients receiving glucocorticoid therapy [28]. That is why, bone mineral density was not assessed in our study group, as the risk fracture can be only partially explained by the decreased bone mineral density.

Glucocorticoids decrease osteocalcin levels [29]. Osteocalcin was recently identified as an important regulator of insulin release and peripheral insulin sensitivity, given the fact that glucocorticoid therapy increases not only the risk of osteoporosis, butalso those of diabetes and metabolic syndrome [22,30].

Deoxypyridinoline is formed during maturation of extracellular collagen fibrils and its measurement in urine provides a valid clinical marker of collagen degradation. After bone degradation, deoxypyridinoline is released into the blood stream and excreted directly into urine with no further systemic metabolism. High urinary deoxypyridinoline levels associated with vertebral fracture risk characterize both premenopausal and postmenopausal women on glucocorticoid therapy [31].

\section{Table 3}

CHANGES IN BIOCHEMICAL BONE MARKERS AFTER GLUCOCORTICOID TREATMENT CESSATION

\begin{tabular}{|l|l|l|l|l|l|}
\hline & Baseline & & Values at 7-9 months after & & \\
& values & & glucocorticoid withdrawal & & \\
\hline & Mean & \pm SD & Mean & \pm SD & P \\
\hline Age & 42.8 & \pm 15 & 50.70 & \pm 15 & $\approx 0.05$ \\
\hline Osteocalcin (ng/mL) & 16.3 & \pm 11.5 & 20.1 & \pm 15 & NS \\
\hline Urine free deoxypyridinoline (nmol/mmol & 10.13 & \pm 4.7 & 7.4 & \pm 2.5 & $\approx 0.05$ \\
creatinine) & & & & & \\
\hline
\end{tabular}




\section{Conclusions}

The alteration of bone turnover occurs during the progression of rheumatoid arthritis, which can be reflected by various markers. The measurement of osteocalcin or urinary deoxypyridinoline helps monitoring the effects of glucocorticoid therapy on rheumatoid arthritis patients. Glucocorticoid use in rheumatoid arthritis is associated with increased bone resorption and reduced bone formation, as signalled by the variation of these bone markers after the withdrawal of glucocorticoid therapy: a decrease in deoxypyridinoline and an increase in osteocalcin levels. Therefore, our RA patients treated with glucocorticoids have routine osteoporosis tests, receive Vitamin D and calcium supplementation and are encouraged to adopt a more active lifestyle.

\section{References}

1.BASCHANT, U., LANE, N.E., TUCKERMANN, J ., Nat. Rev. Rheumatol., 8, nr. 11, 2012, p. 645

2.HARDY, R., COOPER, M.S., Nat. Rev. Rheumatol., 14, nr. 10, 2018, p. 566

3.DAVID, S., KNIELING, A., DAMIAN, S.I., DIAC, M., SANDU, I., IOV, T., Study on Forms of Intoxication with Cocaine and Evolutionary Aspects, Rev.Chim.(Bucharest), 69, no. 5, 2018, p. 1216

4.PERJU DUMBRAVA, D., RADU, C.C., DAVID, S., IOV, T., IOV, C.J., SANDU, I., ILIESCU, D.B., The Importance of Alcohol Testing by Gas Chromatography vs the Cordebard Classical Method Modified in the Medico Legal Investigation, Rev.Chim.(Bucharest), 69, no. 9, 2018, p. 2407

5.HUNEA, I., DAMIAN, S.I., RADU, C.C., MOLDOVEANU, S., IOV, T., Postmortem Specificity of Troponin for Acute Miocard Infarction Diagnosis throug Qualitative Dosing from Pericardial Fluid, Rev.Chim.(Bucharest), 69, no. 9, 2018, p. 2482

6.HEINLEN, L., HUMPHREY, M.B., Osteoporos. Int., 28, nr. 10, 2017, p. 2801

7.FEEHAN, L.M., LI, L.L., MCKAY, H.A., BMC Musculoskelet. Disord., 18, nr. 1, 2017, p. 521

8.SACHELARIE, L., FARCAS, D.M., DARTU, L., VASILIU, M., DARABA, O., NAZARIE, S., MOCANU, C., BURLUI, V., Comparative study of diseases of the stomatognathic system and specific parameters of osteoporosis, OSTEOPOROSIS INTERNATIONAL, 27, nr. 2, 2016, p. 845 9.SACHELARIE, L., DOROFTEI, C., REZLESCU, E., Microstructure and magnetic and electrical properties of low-temperature sintering $\mathrm{Ni}$ $\mathrm{Zn}, \mathrm{Li}-\mathrm{Zn}$ and $\mathrm{Mg}-\mathrm{Zn}-\mathrm{Cu}$ ferrites without and with addition of lead oxide, J OURNAL OF OPTOELECTRONICSAND ADVANCED MATERIALS, 12 , nr. 4, 2010, p. 864
10.LEMS,W.F., Ann. N. Y. Acad. Sci., 1318, 2014, p. 50

11.COMBE B., LANDEWE R., DAIEN C.I., et al. Ann. Rheum. Dis., 76, nr. 6, 2017, p. 948

12.FIEHN C., Dtsch. Med. Wochenschr., 141, nr. 22, 2016, p. 1651

13.CHENG, T.T., LAI, H.M., YU, S.F., CHIU, W.C., HSU, C.Y., CHEN, J .F., CHEN, Y.C., J. Investig. Med., 66, nr. 6, 2018, p. 1004

14.WELDON D. Ann. Allergy Asthma Immunol., 103, nr. 1, 2009, p. 3

15.CREMERS, S., GARNERO, P., SEIBEL, M.J. Biochemical markers of bone metabolism. In: BILEZIKIAN JP, RAISZ LG, MARTIN TJ (eds.)., Principles of Bone Biology, 3rd Edition, Elsevier, San Diego, 2008, p. 1857-1881

16.SYVERSEN, S.W., HAAVARDSHOLM, E.A., BOYESEN, P., GOLL, G.L., OKKENHAUG, C., GAARDER, P.I., VAN DER HEIJDE, D., KVIEN, T.K., Ann. Rheum. Dis., 69, 2010, p. 845

17.SHAW, N., HÖGLER, W. Biochemical markers of bone metabolism., In: Pediatric Bone, 2nd Ed., 2012, Elsevier, p. 361-381

18.NAYLOR, K.E., EASTELL, R., Biochemical markers in bone disease. In: HOCHBERG MC, SILMAN AJ, SMOLEN JS (eds.)., Rheumatology, 6th Edition, Elsevier Saunders, Oxford, 2014, p. 1656-1662

19.ROBINSON, W.H., LINDSTROM, T.M., CHEUNG, R.K., SOKOLOVE, J., Nat. Rev. Rheumatol., 9, nr. 5, 2013, p. 267

20.GARNERO, P., IBMS BoneKEy, 5, nr. 3, 2008, p. 84

21.SIEBUHR, A.S., HE, Y., GUDMANN, N.S., GRAM, A., KJELGAARDPETERSEN, C.F., QVIST, P., KARSDAL, M.A., BAY-JENSEN, A.C., Biomark. Med., 8, nr. 5, 2014, p. 713

22.FERRON, M., LACOMBE, J., Arch. Biochem. Biophys., 561, 2014, p. 137

23.BLAVNSFELDT, A.G., DE THURAH, A., THOMSEN,. M.D., TARP, S., LANGDAHL, B., HAUGE, E.M., Bone, 114, 2018, p. 172

24.VAN SCHAARDENBURG, D., NIELEN, M.M., LEMS, W.F., TWISK, J.W., REESINK, H.W., VAN DE STADT, R.J., VAN DER HORST-BRUINSMA, I.E., DE KONING, M.H., HABIBUW, M.R., DIJ KMANS, B.A., Ann. Rheum. Dis., 70, nr. 6, 2011, p. 1173

25.VLOT, M.C., DEN HEIJ ER, M., DE JONGH, R.T., VERVLOET, M.G., LEMS, W.F., DE J ONGE, R., OBERMAYER-PIETSCH, B., HEIJ BOER, A.C., Bone, 114, 2018, p. 215

26.KHOJ AH, H.M., AHMED, S., ABDEL-RAHMAN, M.S., ALKHALIL, K.M., HAMZA, A.B., J. Bone Miner. Metab., 35, 2017, p. 529

27.TADA, M., INUI, K., SUGIOKA, Y., MAMOTO, K., OKANO, T., KOIKE, T., NAKAMURA, H., Osteoporos Int., 27, nr. 2, 2016, p. 729

28.HENNEICKE, H., GASPARINI, S.) ., BRENNAN-SPERANZA, T.C., ZHOU, H., SEIBEL, M.J., Trends Endocrinol. Metab., 25, nr. 4, 2014, p. 197 29.FERREIRA, J F., AHMED MOHAMED, A.A., EMERY, P., Rheum. Dis. Clin. North Am., 42, nr. 1, 2016, p. 33

30.COOPER, M.S., SEIBEL, M.J., ZHOU, H., Bone, 82, 2016, p. 64 31.KAJI, H., YAMAUCHI, M., YAMAGUCHI, T., SUGIMOTO, T., Osteoporos. Int., 21, nr. 9, 2010, p. 1585

Manuscript received: 12.08 .2018 